\title{
Effects of space flight on ovarian-hypophyseal function in postpartum rats
}

\author{
H. W. Burden ${ }^{1}$, J. Zary ${ }^{1}$, I. E. Lawrence ${ }^{1}$, P. Jonnalagadda ${ }^{1}$, M. Davis ${ }^{2}$ \\ and C. A. Hodson ${ }^{2}$ \\ ${ }^{\mathrm{I}}$ Department of Anatomy and Cell Biology; and 'Department of Obstetrics and Gynecology, \\ School of Medicine, East Carolina University, Greenville, NC 27858-4354, USA
}

\begin{abstract}
The effect of space flight in a National Aeronautics and Space Administration (NASA) shuttle was studied in pregnant rats. Rats were launched on day 9 of gestation and recovered on day 20 of gestation. On day 20 of gestation, rats were unilaterally hysterectomized and subsequently allowed to go to term and deliver vaginally. There was no effect of space flight on pituitary and ovary mass postpartum. In addition, space flight did not alter healthy and atretic ovarian antral follicle populations, fetal wastage in utero, plasma concentrations of progesterone and luteinizing hormone (LH) or pituitary content of follicle stimulating hormone (FSH). Space flight significantly increased plasma concentrations of FSH and decreased pituitary content of LH at the postpartum sampling time. Collectively, these data show that space flight, initiated during the postimplantation period of pregnancy, and concluded before parturition, is compatible with maintenance of pregnancy and has minimal effects on postpartum hypophyseal parameters; however, none of the ovarian parameters examined was altered by space flight.
\end{abstract}

\section{Introduction}

Most mature ovarian follicles in rats release one ovum at ovulation (Brambell, 1956; Bocharov, 1966) and if the reproductive process is $100 \%$ efficient, the number of corpora lutea of pregnancy will equal the number of young delivered. In rats this usually does not occur because of conceptus loss during the pre- and postimplantation phases of pregnancy (Nalbandov, 1964). Nonetheless, the ratio of corpora lutea to young delivered (fecundity ratio) is a useful index of fecundity and changes in this index, relative to controls, provide a means of evaluating effects of different treatments during pregnancy on the number of live young delivered. During pregnancy, the rat ovary contains various sizes of antral follicles, and there is a continuous partial elimination of these follicles by atresia (Greenwald, 1966; Osman, 1986). Atresia occurs by apoptosis (Hsueh et al., 1994) and this important process, which regulates the number of oocytes available for ovulation, is influenced by many extra- and intraovarian factors (Guraya, 1985). The rat has a full complement of preovulatory follicles soon after delivery (Rebar et al., 1969; Ying et al., 1973; Mori et al., 1974; Osman, 1986) in preparation for the postpartum oestrus and ovulation that occur in this species (Blandau and Soderwall, 1941).

In the present study, we examined the effects of space flight on the postpartum fecundity ratio and numbers of healthy and atretic ovarian antral follicles. In addition, the concentration of plasma progesterone, $\mathrm{LH}$, and FSH and the pituitary content of LH and FSH is reported. The animals had experienced space

Received 7 June 1996. flight during days 9-20 of gestation in a National Aeronautics and Space Administration (NASA) space shuttle.

\section{Materials and Methods}

\section{Animals and treatments}

This study was conducted in accordance with all regulations specified in Principles of Laboratory Animal Care (National Institutes of Health publication No. 86-23, revised 1985). Sperm positive Sprague-Dawley rats (Taconic Farms, Germantown, NY) were shipped from the vendor via air freight to Kennedy Space Center (KSC), Florida, on day 2 of gestation (day $1=$ morning on which spermatozoa are present in the vagina). Pregnancy was confirmed on day 7 of gestation by anaesthetizing animals with isoflurane (IsoFlo, Abbott Labs, North Chicago, IL) vapour using a nonrebreathing rodent anaesthesia unit (Viking Products, Medford Lakes, NJ) and counting and recording the number of decidual swellings in each uterine horn. On day 8 of gestation, ten pregnant rats, each with at least five decidual swellings in each uterine horn, were placed into NASA flight cages (animal enclosure modules, AEMs, five rats per cage), loaded onto the mid-deck of the space shuttle, and launched into orbit on day 9 of gestation. On day 20 of gestation, the space shuttle landed at Edwards Air Force Base, CA. Approximately $3 \mathrm{~h}$ after landing, flight animals were recovered, anaesthetized with isoflurane, and subjected to unilateral hysterectomy to provide fetal material from one horn to investigators identified by NASA to study selected fetal parameters. The number of healthy fetuses in the 
removed horn was recorded. After unilateral hysterectomy, the animals were allowed to recover and deliver vaginally. There were three groups ( $n=10$ each group) of control animals at $\mathrm{KSC}$ in the study. A synchronous control group, delayed $24 \mathrm{~h}$ with reference to the flight group, received the same surgeries and was housed five rats per AEM and exposed to all flight conditions (identical temperature, lighting and humidity) except microgravity. Vivarium control group 1 did not receive any surgery and was housed in a vivarium in clear polycarbonate cages. Vivarium control group 2 received only a unilateral hysterectomy on day 20 of gestation but otherwise was housed like the vivarium control group 1. Body masses of synchronous control and vivarium control 2 groups were comparable with those of the flight group on day 8 of gestation, the day the flight group was loaded into the shuttle (flight, $216.6 \pm 2.8 \mathrm{~g}$; synchronous control, $223.0 \pm 5.7 \mathrm{~g}$; vivarium control $2,222.8 \pm 3.3 \mathrm{~g}$ ). For determination of the duration of pregnancy, zero hour was designated as 12:00 midnight prior to detection of spermatozoa in the vagina.

\section{Blood and tissue processing}

Approximately $3 \mathrm{~h}$ after delivery, rats were anaesthetized with isoflurane and blood was withdrawn from the abdominal aorta into heparinized syringes. Blood was centrifuged at $2000 \mathrm{~g}$ and plasma stored at $-70^{\circ} \mathrm{C}$ until FSH, LH, and progesterone analysis.

The pituitary was removed, weighed to the nearest $0.1 \mathrm{mg}$, frozen on dry ice, and stored at $-70^{\circ} \mathrm{C}$ until FSH and LH analysis. Ovaries were removed, trimmed, weighed to the nearest $0.1 \mathrm{mg}$, and immersed in Bouin's fixative. After fixation for at least $48 \mathrm{~h}$, ovaries were dehydrated, embedded in paraffin wax, serially sectioned at $10 \mu \mathrm{m}$, and stained with haematoxylin and eosin. Follicles and corpora lutea were counted in both ovaries of each animal. The procedure for counting follicles has been reported by Burden et al. (1986). Briefly, each section was examined and antral follicles containing an oocyte with a nucieolus were measured. The maximum diameter and a diameter at right angles to it were measured to obtain a mean diameter for each such follicle. Follicles were designated as atretic if they contained either 10 or more granulosa cells with pyknotic nuclei or if the oocyte nucleus was pyknotic. Additional changes noted, but not always present, were resumption of meiosis, infiltration of the follicle with white blood cells, and fragmentation of the oocyte. All healthy and atretic antral follicles $>200 \mu \mathrm{m}$ were measured and assigned to one of three size classifications: 201-400, 401-570, and $>570 \mu \mathrm{m}$ diameter. Since absolute numbers of follicles varied, numbers of atretic and healthy follicles are expressed as percentages of the total follicular population counted.

\section{$L H$ and $F S H$ radioimmunoassay}

Pituitaries were homogenized in PBS, pH 7.4. Pituitary content and plasma concentration of $\mathrm{LH}$ and $\mathrm{FSH}$ were measured by radioimmunoassay (RIA) using procedures previously validated in our laboratory (Burden et al., 1980). Reagents for the RIA were supplied by the Hormone Distribution Program of the National Institutes of Health and values are expressed in terms of LH or FSH RP1 standards. Assays were performed by the double-antibody method using the instructions enclosed with the kits. All samples were run in the same RIA. The sensitivity of the LH and FSH RIA was $12.5 \mathrm{ng} \mathrm{ml} \mathrm{m}^{-1}$ and $20 \mathrm{ng} \mathrm{ml} \mathrm{m}^{-1}$, respectively. Within assay variance was less than $10 \%$.

\section{Progesterone radioimmunoassay}

Plasma concentrations of progesterone were measured using RIA procedures previously validated in this laboratory (Renegar et al., 1992). Sensitivity, blanks, accuracy, and precision were determined in quadruplicate by measuring, respectively, standard quantities of hormone, blank test tubes, and pooled plasma by the procedure used for plasma samples.

\section{Statistical analysis}

Percentage data were subjected to arcsin transformation before analysis. Multisample numerical data between groups were analysed by one way ANOVA. If significance was found, group differences were ascertained by the Newman-Keuls test.

\section{Results}

\section{Body mass, duration of pregnancy, and organ mass}

Space flight during days 9-20 of gestation did not affect body mass gain during this interval of pregnancy. At recovery on day 20 of gestation, the flight group had gained $45.7 \pm 2.0 \%$ body mass during this period, while the synchronous control group gained $42.4 \pm 1.7 \%$. Spaceflight had no effect on the duration of pregnancy (Table 1). Animals delivered pups vaginally from the remaining horn in all groups during the interval from $13: 00 \mathrm{~h}$ on day 22 of gestation to 15:00 h on day 23 of gestation (all deliveries reported in Eastern time). Two animals in the flight group and one in the synchronous control group had not delivered at 15:00 h on day 23 of gestation and pups from these three animals were delivered by caesarean section at $15: 00 \mathrm{~h}$ on day 23 of gestation. Space flight did not alter the mass of the pituitaries and ovaries in postpartum rats (Table 1).

\section{Ovarian follicles}

Space flight during days 9-20 of gestation did not alter the number of postpartum healthy ovarian follicles in any of the size ranges studied (Table 2 ). In addition, there was no effect of space flight on the number of atretic follicles in the size ranges evaluated (Table 2).

\section{Ovarian corpora lutea: fecundity ratios}

The mean number of corpora lutea (both ovaries) in postpartum rats varied from 16.0 to 18.7 in different groups. These differences were not significant $(P>0.05)$. The mean number of decidual swellings at day 7 of gestation in the flight and synchronous control groups was identical (Table 3). By 
Table 1. Duration of pregnancy ( $\mathrm{h}$ ), and wet mass ( $\mathrm{mg} \pm$ SEM) of pituitary and ovaries in flight, synchronous controls (delayed $24 \mathrm{~h}$; same caging, temperature, humidity as flight), vivarium control I (no surgery, standard laboratory housing), and vivarium control 2 (unilateral hysterectomy day 20 of gestation, standard laboratory housing) postpartum rats

\begin{tabular}{llccc}
\hline Group & $\begin{array}{c}\text { Duration of } \\
\text { pregnancy }\end{array}$ & Pituitary & $\begin{array}{c}\text { Left } \\
\text { ovary }\end{array}$ & $\begin{array}{c}\text { Right } \\
\text { ovary }\end{array}$ \\
\hline Flight & $528.8 \pm 2.5^{\mathrm{a}}$ & $12.2 \pm 0.5^{\mathrm{a}}$ & $48.5 \pm 3.0^{\mathrm{a}}$ & $55.7 \pm 2.3^{\mathrm{a}}$ \\
Synchronous control & $533.1 \pm 3.1^{\mathrm{a}}$ & $12.9 \pm 0.4^{\mathrm{a}}$ & $51.5 \pm 2.9^{\mathrm{a}}$ & $50.2 \pm 3.7^{\mathrm{a}}$ \\
Vivarium control 1 & $532.6 \pm 3.0^{\mathrm{a}}$ & $12.4 \pm 0.3^{\mathrm{a}}$ & $48.6 \pm 3.8^{\mathrm{a}}$ & $51.9 \pm 2.5^{\mathrm{a}}$ \\
Vivarium control 2 & $534.1 \pm 1.5^{\mathrm{a}}$ & $13.3 \pm 0.3^{\mathrm{a}}$ & $55.1 \pm 4.1^{\mathrm{a}}$ & $53.5 \pm 4.3^{\mathrm{a}}$ \\
\hline
\end{tabular}

${ }^{a}$ Within each column, means bearing identical superscripts are not significantly different $(P>0.05)$.

Table 2. Percentage of healthy and atretic ovarian follicles in flight, synchronous controls (delayed $24 \mathrm{~h}$; same caging, temperature, humidity as flight), vivarium control 1 (no surgery, standard laboratory housing), and vivarium control 2 (unilateral hysterectomy day 20 of gestation, standard laboratory housing) postpartum rats

\begin{tabular}{|c|c|c|c|c|c|c|}
\hline \multirow[b]{2}{*}{ Group } & \multicolumn{2}{|c|}{ Follicles $201-400 \mu \mathrm{m}$ diameter $(\%)$} & \multicolumn{2}{|c|}{ Follicles $401-570 \mu \mathrm{m}$ diameter (\%) } & \multicolumn{2}{|c|}{ Follicles over $570 \mu \mathrm{m}$ diameter $(\%)$} \\
\hline & Healthy & Atretic & Healthy & Atretic & Healthy & Atretic \\
\hline Flight & $35.9 \pm 1.9^{a}$ & $46.8 \pm 1.6^{\mathrm{a}}$ & $8.1 \pm 1.0^{a}$ & $4.7 \pm 0.9^{a}$ & $4.1 \pm 0.8^{\mathrm{a}}$ & $0.2 \pm 0.1^{a}$ \\
\hline Synchronous control & $35.6 \pm 2.2^{\mathrm{a}}$ & $49.0 \pm 2.0^{a}$ & $6.8 \pm 1.0^{\mathrm{a}}$ & $3.7 \pm 0.6^{\mathrm{a}}$ & $4.1 \pm 0.6^{\mathrm{a}}$ & $0.5 \pm 0.4^{\mathrm{a}}$ \\
\hline Vivarium control 1 & $37.4 \pm 1.4^{\mathrm{a}}$ & $47.8 \pm 1.8^{\mathrm{a}}$ & $7.6 \pm 0.9^{a}$ & $2.4 \pm 0.4^{a}$ & $4.3 \pm 0.6^{\mathrm{a}}$ & $0.2 \pm 0.1^{\mathrm{a}}$ \\
\hline Vivarium control 2 & $38.6 \pm 1.6^{\mathrm{a}}$ & $46.1 \pm 1.6^{\mathrm{a}}$ & $6.7 \pm 0.6^{a}$ & $4.0 \pm 0.5^{\mathrm{a}}$ & $3.8 \pm 0.8^{\mathrm{a}}$ & $0.4 \pm 0.1^{a}$ \\
\hline
\end{tabular}

Values are mean \pm SFM.

${ }^{a}$ Within each column, means bearing identical superscripts are not significantly different $(P>0.05)$.

Table 3. Number of corpora lutea, decidual swellings at day 7 of gestation, fecundity ratio at day 7 of gestation, live conceptuses at day 20 of gestation plus term and fecundity ratio at day 20 of gestation plus term in flight, synchronous controls (delayed $24 \mathrm{~h}$; same caging, temperature, humidity as flight), vivarium control 1 (no surgery, standard laboratory housing), and vivarium control 2 (unilateral hysterectomy day 20 of gestation, standard laboratory housing) postpartum rats

\begin{tabular}{lccccc}
\hline Group & $\begin{array}{c}\text { Number of } \\
\text { corpora } \\
\text { lutea* }\end{array}$ & $\begin{array}{c}\text { Number of } \\
\text { decidual } \\
\text { swellings* }\end{array}$ & $\begin{array}{c}\text { Fecundity } \\
\text { ratio }^{\dagger}\end{array}$ & $\begin{array}{c}\text { Number of } \\
\text { live } \\
\text { conceptuses* }\end{array}$ & $\begin{array}{c}\text { Fecundity } \\
\text { ratio }^{\ddagger}\end{array}$ \\
\hline Flight & $16.0 \pm 1.0$ & $13.1 \pm 0.3$ & $84.4 \pm 4.9$ & $11.8 \pm 0.6$ & $77.0 \pm 5.7$ \\
Synchronous control & $17.7 \pm 1.3$ & $13.1 \pm 0.2$ & $76.6 \pm 4.1$ & $11.7 \pm 0.6$ & $67.7 \pm 3.3$ \\
Vivarium control 1 & $18.7 \pm 1.6$ & - & - & $11.2 \pm 0.4$ & $64.5 \pm 5.0$ \\
Vivarium control 2 & $16.3 \pm 1.3$ & - & - & $11.3 \pm 0.7$ & $73.3 \pm 7.0$ \\
\hline
\end{tabular}

*Mean \pm SEM.

${ }^{+}$Number of decidual swellings divided by number of corpora lutea.

${ }^{\ddagger}$ Number of live conceptuses removed at unilateral hysterectomy plus number of live young delivered from contralateral horn divided by number of corpora lutea

comparing numbers of corpora lutea postpartum with numbers of decidual swellings at day 7 of gestation, it can be seen (Table 3) that the resulting fecundity ratios between the two groups is not different. Likewise, by comparing numbers of corpora lutea postpartum to the number of live young at term (numbers of live young at term $=$ number of fetuses in the horn removed at day 20 of gestation plus the number of live young delivered from the remaining horn), it can be seen (Table 3) that the resulting fecundity ratios between the two groups are not different.

\section{Plasma hormone concentrations}

Space flight had no effect on the plasma concentration of progesterone or $\mathrm{LH}$ postpartum but increased $(P<0.04)$ the 
Table 4. Concentration of plasma progesterone, LH, FSH and pituitary content of LH and FSH in flight, synchronous controls (delayed $24 \mathrm{~h}$; same caging, temperature, humidity as flight), vivarium control 1 (no surgery, standard laboratory housing), and vivarium control 2 (unilateral hysterectomy day 20 of gestation, standard laboratory housing) postpartum rats

\begin{tabular}{lccccc}
\hline Group & $\begin{array}{c}\text { Progesterone } \\
\left(\mathrm{ng} \mathrm{ml}^{-1}\right)\end{array}$ & $\begin{array}{c}\text { LH } \\
\left(\mathrm{ng} \mathrm{ml}^{-1}\right)\end{array}$ & $\begin{array}{c}\text { FSH } \\
\left(\mathrm{ng} \mathrm{ml}^{-1}\right)\end{array}$ & $\begin{array}{c}\text { Pituitary LH } \\
\left.(\mu \mathrm{g} \mathrm{mg})^{-1}\right)\end{array}$ & $\begin{array}{c}\text { Pituitary FSH } \\
\left.(\mu \mathrm{g} \mathrm{mg})^{-1}\right)\end{array}$ \\
\hline Flight & $4.2 \pm 0.8^{\mathrm{a}}$ & $126.7 \pm 55.9^{\mathrm{a}}$ & $173.4 \pm 32.5^{\mathrm{a}}$ & $9.3 \pm 1.1^{\mathrm{a}}$ & $9.9 \pm 0.8^{\mathrm{a}}$ \\
Synchronous control & $5.2 \pm 0.6^{\mathrm{a}}$ & $129.8 \pm 32.4^{\mathrm{a}}$ & $100.9 \pm 19.2^{\mathrm{ab}}$ & $15.1 \pm 1.7^{\mathrm{b}}$ & $9.0 \pm 0.5^{\mathrm{a}}$ \\
Vivarium control 1 & $3.9 \pm 0.9^{\mathrm{a}}$ & $73.6 \pm 15.8^{\mathrm{a}}$ & $83.9 \pm 10.1^{\mathrm{b}}$ & $15.7 \pm 1.4^{\mathrm{b}}$ & $9.9 \pm 0.5^{\mathrm{a}}$ \\
Vivarium control 2 & $4.8 \pm 0.5^{\mathrm{a}}$ & $213.4 \pm 55.1^{\mathrm{a}}$ & $100.3 \pm 23.0^{\mathrm{ab}}$ & $11.9 \pm 1.8^{\mathrm{a}}$ & $7.9 \pm 0.6^{\mathrm{a}}$ \\
\hline
\end{tabular}

Values are means \pm SEM.

al Within each column, values with different superscripts are significantly different $(P<0.05)$.

plasma concentration of FSH (Table 4) relative to the vivarium control 1 group but not the synchronous control or vivarium control 2 groups.

\section{Pituitary content of FSH and LH}

Space flight had no effect on the pituitary content of FSH but decreased $(P<0.02)$ the pituitary content of LH postpartum (Table 4).

\section{Discussion}

The present study investigated the effects of space flight on the postpartum structure and function of the rat ovary and pituitary gland. Space flight during days 9-20 of gestation had no effect on the mass of these organs at postpartum on days 22-23. Rats have a period of oestrus and ovulation after delivery (Blandau and Soderwall, 1941), and the mechanisms that mediate postpartum ovulation are the same as those that control ovulation in normal cyclic rats (Ying et al., 1973). For postpartum ovulation to occur, there must be a sufficient quantity and quality of preovulatory follicles present. We were interested in whether space flight affected the number of preovulatory follicles and the number of growing follicles that would supply oocytes for subsequent ovarian cycles. In addition, we wished to determine whether the rate of atresia was altered by space flight. Since the fate of about $77 \%$ of rat ovarian follicles is atresia (Arai, 1920; Mandl and Shelton, 1959; Byskov, 1978), any disruption of this fundamental ovarian regulatory process could result in an increased or decreased number of ovulatory follicles and a resultant altered fecundity. However, space flight during days 9-20 of gestation had no effect on the numbers of ovarian follicles in any size range studied, either healthy or atretic, in ovaries approximately $3 \mathrm{~h}$ postpartum. This indicates that space flight had no effect on the capacity of the ovary to produce the normal number of preovulatory follicles at the end of pregnancy.

During the normal oestrous cycle of rats, ovulatory follicles are converted into corpora lutea. In the absence of pregnancy or pseudopregnancy induction, corpora lutea secrete progesterone for only 2 days and then regress rapidly (Hashimoto et al., 1968; Smith et al., 1975). If the rat becomes pregnant or pseudopregnant, corpora lutea enlarge and secrete large quantities of progesterone which maintain pregnancy (see review by Gunnet and Freeman 1983). The complex of events that occurs before delivery includes a precipitous drop in circulating progesterone (Wiest et al., 1968; Louis et al., 1978; Renegar et al., 1992), a major controlling event in the delivery process in rats (Csapo and Wiest, 1969). In the present study, flight animals delivered at the same times as controls and as expected, circulating progesterone concentrations were low. Since corpora lutea develop from ovulatory follicles, and since most rat follicles contain only one oocyte (Brambell, 1956), the number of corpora lutea postpartum reflects the number of ova ovulated. Most embryo wastage occurs before implantation (Nalbandov, 1964). Because of the laparotomy at day 7 of gestation, the number of implanted embryos was known. By comparing the number of corpora lutea postpartum with the number of implanted embryos at day 7 of gestation, we determined that there was no significant difference in embryonic wastage between flight and synchronous controls at day 7 of gestation. The ratio of the number of corpora lutea:implantation sites is referred to as the fecundity ratio at day 7 of gestation. For this study, we made the assumption that the number of decidual swellings at day 9 of gestation was the same as recorded at day 7 of gestation. Thus, by comparing the number of corpora lutea postpartum with the number of live fetuses (at day 20 of gestation) and young born at day 22 or day 23 of gestation, we could ascertain the effects of space flight on fetal survival during days 9-20 of gestation. Space flight during this interval of pregnancy had no effect on this fecundity ratio at term. Postpartum gonadotrophin surges occur between 3.5 and $13 \mathrm{~h}$ after delivery (Rebar et al., 1969; Mori et al., 1974), although some rats show rises in circulating gonadotrophin concentrations as early as $2 \mathrm{~h}$ postpartum (Rebar et al., 1969). Sequential blood samples would need to be taken for approximately $2-24 \mathrm{~h}$ postpartum to obtain meaningful data on circulating gonadotrophins at this time. The imposed logistics of the experimental design in the current study allowed only a single plasma sample postpartum for analysis. There was no effect of space flight on plasma concentrations of LH at the postpartum sampling, but statistically, space flight increased plasma concentrations of FSH. Because $\mathrm{LH}$ and FSH are released in a pulsatile manner, there is considerable variance and the biological relevance of this observation is equivocal. 
The pituitary content of LH in rats is low postpartum relative to concentrations at day 20 of gestation (Greenwald, 1966). An inverse relationship between pituitary content and circulating peripheral plasma concentrations of LH has been demonstrated during the first $10 \mathrm{~h}$ after delivery in this species (Rebar et al., 1969). In the present study, space flight rats had a lower pituitary content of this peptide postpartum than did the control groups. It has been hypothesized that low gravity affects hormone packaging within the cytoplasmic secretory granules within cells of the anterior pituitary (Hymer et al., 1992). However, as mentioned above, space flight had no effect on circulating LH. Clearly, more studies need to be conducted to clarify any possibie biological significance of this observation.

In conclusion, the results of the present study show that space flight, when initiated after implantation, when pregnancy is well established, and concluded before delivery, is compatible with fetal growth and development, pregnancy maintenance, and parturition in the rat. Although some statistical differences were noted in hypophyseal parameters, no clear pattern of change was evident and the structure and function of the postpartum ovary was normal in all respects.

This study was supported by NASA Cooperative Agreement NCC 2-866. The authors thank the following people who assisted with animal surgery at KSC: V. Vizir, D. Leonard, T. Schnepp, C. Elan, S. Black, M. Mack, T. Fast, L. Eward, J. Love, G. Price, J. Alberts and A. Ronca. They would also like to express appreciation for the work and support of the astronaut crew of Space Shuttle flight STS-66: Commander, D. R. McMonagle; Pilot, C. L. Brown; and Mission Specialists E. Ochoa, S.E. Parazynski, J. F. Clervoy and especially J. R. Tanner.

\section{References}

Arai $\mathbf{H}(1920)$ On the postnatal development of the ovary (albino rat), with special reference to the number of ova American Journal of Anatomy 27 $405-462$

Blandau RJ and Soderwall AL (1941) Post-parturitional heat and the time of ovulation in the albino rat. Data on parturition Anatomical Record 81 419-431

Bocharov WS (1966) Multiovular follicles in the ovaries of mammals Advances in Soviet Biology 62 139-147

Brambell FWR (1956) Ovarian changes. In Marshall's Physiology of Reproduction 3rd edn vol 1 pp 397-542 Ed. AS Parkes. Longmans Green, London and New York

Burden HW, Lawrence IE, Jr and Hodson, C (1980) Effect of abdominal vagotomy of the pregnant rat on pituitary content of prolactin and gonadotropins IRCS Medical Science 8809
Burden HW, Leonard MJ, Hodson CA, Louis TM and Lawrence IE (1986) Effect of abdominal vagotomy at proestrus on ovarian weight, ovarian antral follicles, and serum levels of gonadotropins, estradiol, and testosterone in the rat Neuroendocrinology 42 449-455

Byskov AG (1978) Follicular atresia. In The Vertebrate Ovary pp 533-562 Ed. RE Jones. Plenum Press, New York

Csapo AI and Wiest WG (1969) An examination of the quantitative relationship between progesterone and maintenance of pregnancy Endocrinology $\mathbf{8 5}$ 735-746

Greenwald GS (1966) Ovarian follicular development and pituitary FSH and LH content in the pregnant rat Endocrinology 79 572-578

Gunnet JW and Freeman ME (1983) The mating-induced release of prolactin: a unique neuroendocrine response Endocrine Reviews 4 44-61

Guraya SS (1985) Biology of Ovarian Follicles in Mammals Springer-Verlag, Berlin

Hashimoto I, Hendricks DM, Anderson LL and Melampy RM (1968) Progesterone and pregn-4-en-200-ol-3-one in ovarian venous blood during various reproductive states in the rat Endocrinology 82 333-341

Hsueh AJW, Billig H and Tsafriri A (1994) Ovarian follicle atresia: a hormonally controlled apoptotic process Endocrine Reviews 15 707-724

Hymer WC, Grindeland R, Krasnov I, Victorov I, Motter K, Mukherjee P, Shellenberger $K$ and Vasques $M$ (1992) Effects of spaceflight on rat pituitary cell function Journal of Applied Physiology 73 151S-157S

Louis TM, Lawrence IE, Jr, Becker RF and Burden HW (1978) Prostaglandin $F_{2 u^{\prime}}$ Prostaglandin $\mathrm{E}_{2}$, progesterone, 20a-dihydroprogesterone and ovarian $20 \alpha$ hydroxysteroid dehydrogenase activity in preparturient pelvic neurectomized rats Proceedings of the Society for Experimental Biology and Medicine 158 631-636

Mandl AM and Shelton M (1959) A quantitative study of oocytes in young and old nulliparous laboratory rats Journal of Endocrinology 18 444-450

Mori J, Nagasawa H, Yanai R and Masaki J (1974) Changes in serum levels of follicle stimulating hormone and luteinizing hormone shortly before and after parturition in rats Acta Endocrinologica 75 491-496

Nalbandov AV (1964) Reproductive Physiology 2nd edn. WH Freeman and Co, San Francisco

Osman P (1986) Morphometric analysis of follicular dynamics in pregnant and pseudopregnant rats Journal of Reproduction and Fertility 76 11-22

Rebar RW, Nakane PK and Midgley AR, Jr (1969) Post-partum release of luteinizing hormone $(\mathrm{LH})$ in the rat as determined by radioimmunoassay Endocrinology 84 1352-1358

Renegar RH, Steel M, Burden HW and Hodson CA (1992) Endocrine parameters associated with disruption of parturition after bilateral pelvic neurectomy Proceedings of the Society for Experimental Biology and Medicine $20128-33$

Smith MS, Freeman ME and Neill JD (1975) The control of progesterone secretion during the estrous cycle and early pseudopregnancy in the rat: prolactin, gonadotropin and steroid levels associated with rescue of the corpus luteum of pseudopregnancy Endocrinology 96 219-226

Wiest WG, Kidwell WR and Balogh K, Jr (1968) Progesterone catabolism in the rat ovary: a regulatory mechanism for progestational potency during pregnancy Endocrinology 82 844-859

Ying, S-Y, Gove S, Fang VS and Greep RO (1973) Ovulation in postpartum rats Endocrinology 92 108-116 